\title{
Migration and torture: Building a map of knowledge
}

\author{
Pau Pérez-Sales, Editor in Chief
}

We already have more than twenty-five years of academic research on migration and torture; the field has developed into an increasingly complex one since the first descriptive and epidemiological studies.

\section{The "refugee crisis"}

The recent war in Syria, added to previous conflicts in Afghanistan, Iran, Iraq, has led to mass displacement, especially since 2015 , to neighbouring countries and Europe, in what has come to be known as the refugee crisis. The concept crisis as applied to Europe is a relative one. According to 2018 UNCHR figures, ${ }^{1}$ while there are 22.5 million refugees in the world, the top hosting countries are Turkey $(2.9 \mathrm{M})$, Pakistan (1.4 M), Lebanon (1 M), Iran (979,000), Uganda $(940,000)$ and Ethiopia $(791,000)$. While $30 \%$ of those living in Lebanon (a country with a very unstable religious and political equilibrium) are refugees, ${ }^{2}$ in Europe the proportion of refugees is marginal in demographic terms, even including the increase in the last two years.

Several episodes have marked the European political confrontation around

1 Resettlement data finder accesed in http://rsq. unhcr.org/en

2 https:/ec.europa.eu/echo/files/aid/countries/ factsheets/lebanon_syrian_crisis_en.pdf the "refugee crisis" in this period. These include, (a) Germany's decision to both open its doors in 2015 and 2016 and accept more than one million refugees, and then subsequently restrict entry in 2017 after the political environment altered due to various factors, including two Islamist attacks attributed to newly arrived refugees; (b) The EU decision in May 2017 to transfer 160,000 asylum seekers that were stuck in Greece and Italy to other European member states was met with widespread resistance. The European Union was not able to fully act on the decision and the transfer could only partially take place. As a result, around 65,000 refugees remained in both countries, and especially on the Greek Islands in precarious conditions; (c) In March 2016, in exchange for political and financial benefits, the EU signed an agreement with Turkey (recognised as $a$ safe country) to accept people being sent back from Greece. In spite of that, only around 2000 persons $^{3}$ were sent back due to resistance of the Greek courts to apply the agreement (Roman, Baird, \& Radcliffe, 2016). Those who were returned faced detention in overcrowded cells and deportation (Ulusoy \& Battjes, 2017).

\footnotetext{
3 http://www.dw.com/en/the-eu-turkey-refugee-
} agreement-a-review/a-43028295 
Europe is now trying similarly unacceptable arrangements with Libya, Egypt, Sudan, and Nigeria, among other countries, countries which can never be considered as safe countries for refugees to be sent back to.

The true refugee crisis is of course that around 4,600 persons are estimated to have died trying to cross the Mediterranean in the 2015-2018 period, ${ }^{4}$ the sufferings of hundreds of migrants exploited, victims of extortion, tortured and abused on their way north, pushed back at borders violating nonrefoulement principles or abandoned to their fate on the sea.

\section{Research on migration and torture}

It is worthwhile attempting a structural map of knowledge of where we are currently with respect to research. Figure 1 is not meant to be exhaustive, but illustrative.

\section{Overarching issues}

The mental health impact of torture: Different reviews since the 1990s have provided strong evidence of the mental health impact of persecution and torture (Johnson \& Thompson, 2008; Momartin, Silove, Manicavasagar, \& Steel, 2003; Steel et al., 2009). Just to mention one, a meta-analysis of 161 articles reporting results from a sample of 81,866 refugees from 40 countries showed that torture emerges as the strongest pre-migration factor associated with PTSD and depression, followed by cumulative exposure to potentially traumatic events (Steel et al., 2009).

Distrust as a cross-cutting element: The impact of hardship and torture is not only measurable in clinical terms though.

4 https://www.opensocietyfoundations.org/explainers/understanding-migration-and-asylum-european-union
As academic research has shown, if one psychological element illustrates the migrant's experience and provides a framework of understanding of his or her inner experience, it is that of trust. The decision to flee for torture survivors is part of a complex process. Voutira \& Harrell-Bond (1995) showed, among others, how adaptive distrust shaped the experience of survivors of war and torture. There is a mixture of individual, community, institutional and social mistrust shaped by the context of violence and menace behind the decision to flee (Lyytinen, 2017). Key decisions during the route that could mean the difference between being dead or alive depended on trusting decisions. For years, mistrust is the norm (Daniel \& Knudsen, 1995). particularly as refugees are often used as a bargaining chip in political disputes amongst countries, traders and local authorities, who often have their own hidden agenda, and NGO's and iNGOs can be unwilling to provide support for an extended period of time (Stedman \& Tanner, 2003).

Country of destination is rarely a decision of the asylum-seeker. Studies show that, at the beginning, the main concern is to find a safe place. Final destination, however, depends on having funds and very circumstantial decisions made in the heat of the moment, as well as being directed by smugglers, police, the military, governments, and/or agencies to particular countries with little choice (Robinson \& Segrott, 2002). Dispersal within a country or between countries can destabilise precarious social networks as well as disrupt the fragile bonds of trust of early psychological care (Griffiths, 2012; Níraghallaigh, 2014)

\section{Crossing borders: when torture happens during flight}

Borders have become places of very serious human rights violations, as the Special Rapporteur against Torture (2018) has noted in his latest thematic report. To give an example, just on the border 
Figure 1: Migration and torture - Psychosocial determinants of health and well-being and right to rehabilitation

Negative factors: $(0)$ No evidence, $\left({ }^{\star}\right)$ Indicative evidence, $(\star \star)$ Strong evidence, $(\star \star \star)$ Conclusive evidence.

Torture is according to UNCAT definition. Torture during migration progress includes where the State fails it's obligation to protect.

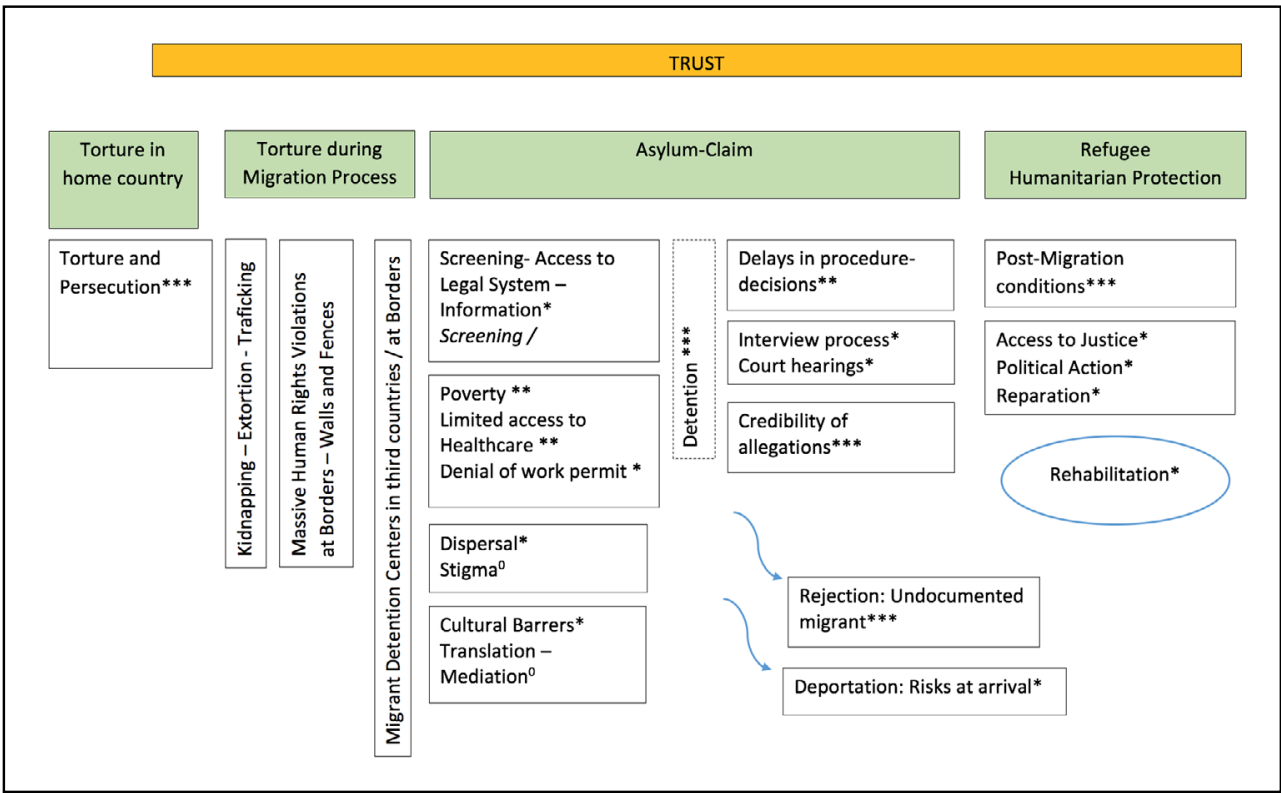

between Guatemala and Mexico, according to official figures and reports of local organizations, ${ }^{5}$ an estimated 20,000 people were reported missing ("Desaparecidos") in the period 2015-2017 at the hands of organised crime and trafficking with the necessary cooperation of the State and local police forces. This is to be added to the general situation in the MexicanUnited States border itself, where there has been an estimated 800 cases of missing people in the last two years. According to independent reports, the US is maintaining a policy of illegal detention of asylum-

5 Centro Fray Matias de Córdoba. http://cdhfraymatias.org/web/. Movimiento Migrante Mesoamericano https://movimientomigrantemesoamericano.org/inicio/ seekers including extreme conditions in cells, indefinite separation of minors from their parents, lack of information and access to legal counsel, victimisation and other forms of coercion to accept returning to Mexico, in what human rights groups and the rapporteur himself have considered as amounting to systemic State torture (Hope Border Institute, 2018; Human Rights First, 2017). Europe pursues similar policies by funding detention centres and coercive actions in North Africa where the systematic violations of human rights including torture and summary executions that take place have been denounced. ${ }^{6,7}$

\footnotetext{
6 See reports in http://ddhhfronterasur2017.org/es/ 7 See reports and maps by Migreurop. http://www. migreurop.org/
} 
There is a special need to address the challenges of migrants who, along their migration route, have suffered violence (including torture by non-state actors and sexual violence). They should be offered similar protection against further abuses and exploitation and to ensure access to basic human rights (to health, housing, education, rehabilitation etc).

\section{Detention centres}

The Global Detention Project (GDT) monitors detention of immigrants in "host" countries, ${ }^{8}$ and has a global map and detailed data of around 2,000 immigrationrelated detention sites across the globe. Within the United States, which is the most dramatic example, there has been a sustained expansion with between 430,000470,000 individuals being recently subject to some form of immigration detention annually compared to numbers as low as 6,000 in 1995 and 16,000 in 1998. Europe has also experienced a rapid expansion of detention, including outsourcing detention to border countries.

There is a large body of literature that analyses the health impact of detention on victims fleeing torture and violence in their countries and indicates that detention substantially worsens the health of asylumseekers (Fazel \& Silove, 2006; Keller et al., 2003; Robjant, Hassan, \& Katona, 2009; Sobhanian, Boyle, \& Bahr, 2006; Storm \& Engberg, 2013). Data show symptoms of depression, anxiety, exacerbation of PTSD, marked increase in reported negative mood states, suicidal ideation and selfdestructive thoughts. In all the studies the impacts are directly related to length of detention. Prolonged or indefinite detention

\footnotetext{
8 https://www.globaldetentionproject.org/
}

per se produces learned helplessness and powerlessness (Storm \& Engberg, 2013). The transnational DEVAS study showed in $23 \mathrm{EU}$ countries that almost half of the detainees in migration centres inside Europe did not understand the reason for their detention and equate their detention centre with that of a prison. Approximately one third referred to clear physical consequences and half described a negative impact on mental health. There was a general sense of indignity among detainees (Jesuit Refugee Service - Europe, 2010). This is specially so in the subgroup of torture survivors (Filges, Montgomery, \& Kastrup, 2018) (Storm \& Engberg, 2013). According to recommendations from the United Nations' High Commissioner for Refugees (UNHCR) (2012) and the Special Rapporteur on Torture (2018), torture survivors and other vulnerable groups should generally not be detained. Health professionals should actively oppose this measure based on ethical and deontological principles (Brooker et al., 2016; Pearman, Psych, Olinga-shannon, \& Hons, 2017)

\section{Accessing the system of protection for torture survivors}

There is an important concern in the antitorture sector that torture survivors who suffer trauma-related mental disorders are being refused protection by countries in which they seek asylum. A pioneering study (Loneragan et al., 2006) followed a consecutive sample $(n=73)$ of recently arrived asylum seekers attending immigration agents in Sydney, Australia. Participants were followed up to assess the outcomes of their refugee applications. Although the participants reported high rates of torture (51\%), and this group is of course at the highest risk of suffering a combination of post-traumatic stress disorder (PTSD) and major depression, neither past torture nor 
current psychiatric disorder predicted the outcomes of refugee applications. Although the Asylum Procedures Directive (European Council, 2013) establishes special measures to detect and properly document torture survivors, ${ }^{9}$ there are serious concerns regarding its proper application (IRCT, 2016)

Faced with the increasing numbers of asylum seekers, a number of initial screening tools - up to 20 documented in academic journals and grey literaturehave been proposed, the majority of large institutions having their own. There are suggestions and formats from national and international bodies including guidelines from the European Union itself (PROTECT Project, 2016)—see also Mewes, Friele, \& Bloemen, (2018) in this issue. The scene is variegated and requires revision as most are non-validated instruments that can be classified into two broad categories: (a) short clinical measures based on abbreviated diagnoses of post-traumatic stress or general psychological distress that can be applied by administrative staff (i.e. Hollifield et al., 2013); and, (b) general indicators of vulnerability (i.e. UNHCR-International Detention Coalition - OAK, 2016). It should be remembered that there is a low to moderate correlation between experiences of torture and psychiatric disorders, and

$9 \quad$ The Asylum Procedures Directive (recast) was adopted by the European Parliament and the Council in 2013 and was to be transposed into Member States' national legislations by July 2015 . The Commission presented in July 2016 a Proposal for a new Asylum Procedure Regulation. Point 31 states that, "National measures dealing with identification and documentation of symptoms and signs of torture or other serious acts of physical or psychological violence, including acts of sexual violence, in procedures covered by this Directive may, inter alia, be based on the (...) Istanbul Protocol." that PTSD is neither the only nor the most likely consequence of torture in the long term. Issues of transcultural validity of screening tools are also relevant. A review of validated measures and more theoretical debate and consensus is needed (Gadeberg \& Norredam, 2016; McColl, McKenzie, \& Bhui, 2008).

\section{Post-migration without status}

Silove and colleagues have been providing sustained evidence of the negative impact on mental health of conditions of reception for asylum seekers in Australia, showing that its impact was even greater than torture and persecution in country of origin (Silove, 2000; Z Steel \& Silove, 2001; Steel et al., 2009). A Norwegian case-control study in an in-patient psychiatric ward found highly significant differences in PTSD prevalence between asylum seekers, living in centres $(n=53,43.3 \%)$, and refugees $(n=45,11 \%)$, associated to the stresses of life in reception centres and the risk of being expelled from the country more than the experiences in countries of origin (Iversen \& Morken, 2004). Other studies have expanded these results to medical conditions (Porter, 2007). In a recent systematic review (Kalt, Hossain, Kiss, \& Zimmerman, 2013), combining data from 23 peer-reviewed studies among asylum-seekers (30\% torture survivors), it was concluded that highly stressful asylumseeking processes produced adverse mental and somatic health effects, associated to specific forms of exclusion linked to social conditions and hostile policy environments.

Whilst these conditions vary from country to country, there are some salient themes:

Poverty: Asylum seekers face economic hardship through an increasingly short and limited system of state social support and assistance even where there is one 
(Allsopp, Sigona, \& Phillimore, 2014). While waiting for a determination decision, they often receive basic temporary benefits, well below the minimum of the country, usually aggravated by the denial of permission to work. This situation can extend for a long period of time. As an example, in a 2013 study for Freedom for Torture, Pettitt reveals that more than half of a sample of 84 torture survivors in the UK asylum system reported that they could never or not often afford to buy enough food of sufficient quality and variety to meet their needs for a nutritionally balanced diet. 34 were never able to buy enough food of any quality to avoid hunger. 53 could not buy adequate winter clothing (Pettitt, 2013). It is hard to imagine the situation of asylum seekers in countries with even lower levels of assistance.

Access to healthcare: According to the HealthQUEST study (Tirado, 2008), most European countries limit the access of migrants and asylum seekers to health care, usually reducing it to basic care and emergencies. The system of free specialised healthcare is usually banned. The study shows that in Europe providing comprehensive adequate care (including mental health) would, paradoxically, save costs. In the United States where there is no national health system, the situation is so precarious that Asgary, Charpentier, \& Burnett (2012) showed in a sample of sub-Saharan asylum seekers (most of them torture survivors) that they had better access to social and health services in their home African countries than in the US.

Stigma: There is growing evidence that perceived discrimination carries a psychological toll. A wide study following a participatory action research process in Scotland showed how this was linked to mental health problems, especially in VoT (Quinn, 2014).

Cultural Barriers: Language and culture have been documented as central sources of stress, particularly in the long term (Montgomery, 2011). The role of cultural mediators is crucial, undoubtedly another insufficiently researched topic.

Access to justice and providing meaning to the experience of torture: Arriving in a host country is, for many survivors, part of a process of social and political commitment which cannot be easily continued. Giving testimony, being part of an ideological or political movement, helping those who remain in their country, and pursuing justice can be essential elements to providing meaning to the experience of torture and to have a sense of continuity in life. The asylum system too often victimises survivors and keeps them in a vulnerable legal position that precludes any possibility of activism or empowerment and the impacts of this are not well researched. (EATIP, GTNM/RJ, CINTRAS, \& SERSOC, 2002; Tay \& Silove, 2017)

\section{Facing assessment}

Abbreviated procedures: McColl (2008) has shown that processes that are too fast-track can preclude proper medical documentation of allegations of torture or persecution.

Delay of decision: In a series of focus group with survivors of torture in UK, the three biggest problems described were uncertainty, lack of perspective and a shortened future associated with endless waiting for a decision (Haoussou, 2017). Although the European Asylum Procedures Directive (European Council, 2013) envisages a maximum of six months for an asylum determination, the decision 
normally takes much longer, sometimes years. At the American border, asylum claimants often spend many years waiting for the adjudication of their cases creating a limbo situation (Haas, 2017). A crosssectional survey with Iraqi refugees whose determinations were pending showed that survivors waiting for a decision generally felt socially isolated and lacking in control over their life circumstances with a strong sense of injustice (Johnston, Allotey, Mulholland, \& Markovic, 2009).

Stress of the interview and court hearings: After initial acceptance, and after a long waiting process, survivors of torture must prepare and undergo an in-depth interview (and sometimes a court hearing) where her fate will be decided. This is not a neutral process. A recent study in Berlin suggested that the asylum interview might decrease posttraumatic avoidance but trigger posttraumatic intrusions (Schock, Rosner, \& Knaevelsrud, 2015). Due to this stress, the interview might have a negative result. Similar studies in other countries have found less conclusive results (Hocking, Kennedy, \& Sundram, 2015)

Medical reports: Some studies show the importance of medical reports for proper documentation of torture. In a sample of close to 2000 asylum-seekers in the US, $89 \%$ of those with a medical report from Physicians for Human Rights (PHR) were granted asylum, compared to the national average of $37.5 \%$ (Lustig, Kureshi, Delucchi, Iacopino, \& Morse, 2008). We need more data on which aspects of forensic assessment in general and the Istanbul Protocol in particular are relevant for an administrative body or court to make a final decision on a protection claim, a much needed demand in the anti-torture sector (Freedom for Torture,
2016; Pérez-Sales, Witcombe, \& Otero Oyague, 2017).

Credibility: It is probably the assessment of the credibility of allegations of torture that is the one of the most complex issues and on which, paradoxically, there is less academic research (Jubany, 2017). On the one hand, there is a debate on whether health professional should make judgments of credibility (Good, 2004). The debate often mistakes the credibility of the victim with the credibility of the victim's account. There is arguably an ethical duty to have a forensic report provided, especially in contexts in which the victim of torture lacks any other evidentiary element, has fled without any documentation, and there are no physical injuries or witnesses that can support her allegations (Pérez-Sales, 2017). This is particularly the case when considering the crude reality that torture survivors are being refused protection in all likelihood due to the difficulties in giving a proper account of the facts (Loneragan et al., 2006; Masinda, 2004).

There are numerous guidelines for credibility assessment of the different institutions and bodies working within the framework of asylum (Gyulai, Kagan, Herlihy, Turner, \& Lilli, 2013; Home Office, 2015; Kane, 2008; Mackey \& Barnes, 2013; Mind, 2010), with very different perspectives and approaches and sometimes conflicting criteria. While in some cases the victim's account is said to be the weakest piece of evidence, in others it is the opposite that is emphasised and guidelines are worked out for the analysis of the narrative and its relationship with sources of corroboration or triangulation. None of the available guides to best practice have been validated and they are in any case only recommendations from experts. We also lack data for comparing 
credibility in this area with credibility in other fields and the standards of proof required (Freedom for Torture, 2016).

It unfortunately remains the case that the asylum determination process relies heavily on remembering and narrating traumatising stories in a convincing way and without contradictions, despite mental health issues.

\section{Deportation}

In 2016 alone, the EU allocated a total of 806 million Euros to activities related to the deportation of migrants, including the expulsion of 113,835 people to the 15 countries with which Europe has signed a repatriation partnership agreement and the financing of migrant centres in countries such as Pakistan or Lybia. This figure would have increased noticeably if the agreement with Turkey had not been a failure ${ }^{10}$ and if transfer among EU members in application of the Dublin procedure were included. ${ }^{11}$ During President Obama's administration, a record 2.5-3 million immigrants were deported in his eight years in office. In 2016, immigrant detention and deportation machinery alone in the US cost 3.3 billion dollars (Baker, 2017). What happens with asylum-claimers who have been rejected and deported? Although some organizations try to keep track of them (Amnesty International, 2017), there is scarce data on their fate. There are some ethnographic

10 http://www.publico.es/internacional/union-europea-agencia-deportacion-masiva-migrantes.html

11 In January 2011, the European Court of Human Rights (EchRT) declared that the transfer of one person from Belgium to Greece in application of the Dublin rules violated Article 3 (torture and inhuman or degrading treatment or punishment) and Article 13 (effective remedy) of the European Chart of Human Rights. Following this decision, most of the member states of the European Union stopped Dublin transfers to Greece. studies on the hardships of reintegration after deportation for economic migrants (e.g. Khosravi, 2018) but literature is scarce on rejected asylum claimants.

The organisation Justice First followed in 2011 a sample of Congolese people deported from France and found out that all failed asylum seekers had been imprisoned, tortured, forced to pay a ransom, raped or subjected to sexual harassment upon their return (Ramos, 2011). Reports from Freedom for Torture (2012) and Human Rights Watch (2012) have documented the systematic detention and torture of Tamils who were rejected asylum claimants and deported to Sri Lanka. Similar data have been reported for deportees to Eritrea, Malta, Libya including summary executions of deportees in Sudan (Alpes, Blondel, Preiss, \& Monras, 2017). There are documented cases of detention and torture of Ugandan citizens that demanded asylum due to being a member of the LGTBQ community (Onyoin, 2017), and already mentioned is the fate of people deported to Turkey in application of the EU-Turkey agreement. This data should not be a surprise. In many countries, the deported person is handed to the national authorities on arrival. Having claimed asylum is viewed as suspicious and the person is often immediately detained and interrogated. All together, these studies suggest that there is a real danger for deported people and this must be the responsibility of deporting authorities that do not have a post-deportation follow-up system (Stefanovska, 2016). Additionally, a Rights Disability International campaign claims that deporting people with severe mental disorders or disabilities to countries where they will have no access to proper care or treatment or be secluded in institutions with conditions that can amount to torture 
should be enough to stop deportation and humanitarian protection should always be granted (Rosenthal, 2018). ${ }^{12}$

\section{The top of the vulnerability pyramid: undocumented migrants}

The alternative for survivors whose application has been rejected is to stay undocumented in the host country in even worst conditions than before. If asylum seekers and refugees suffer poverty, stigma, lack of health services or a work permit, this is to be added to having to hide from police, being defenceless from crime and violence and working in the underground economy. Overwhelming data show that this is the group with the highest risk of severe mental health disorders. One study, among many, in Zurich (Switzerland) showed that more than $80 \%$ had at least one clinically significant symptom, and more than $50 \%$ fulfilled the criteria for PTSD. This should come as no surprise as more than $60 \%$ had suffered imprisonment and 30\% torture. The prevalence of torture was slightly lower than those of asylum seekers, but the prevalence of mental health problems was higher. The study showed, again, not only that refugee and humanitarian decision-making procedures may be failing but also that undocumented migrants are probably the most vulnerable and affected of populations due to an aggravation of premigration symptoms and the impossibility of access to treatment according to their right to rehabilitation (Mueller, Schmidt, Staeheli, \& Maier, 2011).

\section{Once status is granted: 'El Dorado'}

The long journey finally ends for an estimated $30-40 \%$ of torture survivors that

\footnotetext{
12 https://www.driadvocacy.org/
}

ask for international protection obtaining it (Loneragan et al., 2006; Mueller et al., 2011; UNHCR, 2017). The majority is, thus, undetected or rejected. There is a large body of literature showing that the refugee population, even with protection status, has very high levels of psychological suffering resulting from their pre-migration experiences, but particularly from life in the new host country (Porter, 2007; Porter \& Haslam, 2005). A decent standard of living is not guaranteed.

\section{Right to rehabilitation}

Torture survivors have a right to rehabilitation, as set out in the Convention against Torture and General Comment No. 3. Programs for VoT who move about are a challenge. There is a need for short-term interventions that follow the do-no-harm principles in contexts where it might not be the time to talk. This creates a special set of conditions for rehabilitation programs that deserve special research, including long-term follow-up and non-clinical measures.

\section{Where next?: Concluding remarks}

The over twenty-five years of research in the field appears to provide conclusive evidence regarding the negative impact on torture survivors of human right violations taking place throughout the migration continuum.

This idea of a migration continuum deserves special attention. Migrants who along their migration route have been suffering violence (including torture by non-state actors, sexual violence, and being unable to access basic conditions that respect human dignity) should be also offered protection and access to basic human rights (to health, housing, education, rehabilitation etc).

Figure 1 is intended to show a summary of the relationship between mental health 
and well-being and pre- and post-migration factors and the amount and strength of available evidence. Although we need more studies on psychosocial determinants during the asylum claim process, there is strong evidence on the impact of poverty and limitations of access to health care. Most of the research highlighted here is in relatively well-off host countries which reflects the absence of literature in more complex situations (e.g. Lebanon and Greece, not to mention other neighbouring countries to refugee-producing countries in the rest of the world). More research is especially needed regarding the migration process itself and the impact of massive human rights violations at borders, migrant detention centres in third countries, and by State and Non-State actors on victims of persecution and torture fleeing from their country. This also applies to research on what happens to people being denied protection and deported to their countries of origin. Although there are indicative data, more research is also needed on the screening process and appropriateness of detention of torture survivors and vulnerable populations, the impact of the asylum process and interviews, on the role of translators and cultural mediators, and the effect of policies of dispersal and delays in procedure decisions. With respect to proper identification procedures, the need is poignant and urgent. Finally, we still lack more research and stronger evidence on the efficacy of rehabilitation programs for migrant torture survivors.

\section{In this issue}

Some of these topics are addressed in the Special Section of this issue, the papers of which have been developed from presentations at the International Society for Health and Human Rights' 2017 tri-annual conference in Novisad (Serbia) on Mental health, mass people displacement and ethnic minorities, and from a call from the Journal. It has been made possible thanks to the financial support of the Danish Ministry of Research. It starts with a paper by Caterina Spissu and colleagues from Médecins Sans Frontières teams in Rome exploring the difficulties in early identification of torture victims by non-professionals working in front-line resources. This is followed by a the study on the psychometric evaluation of the Protect Questionnaire mentioned above by Ricarda Mewes, Boris Friele, Evert Bloemen. Simone de la Rie, Jannetta Bos, Jeroen Knipscheer and Paul Boelen from Zentrum 45 in the Nertherlands present several case studies paradigmatic of the difficulties of the cases they attend, as do Gail Womersley and colleagues at Médecins Sans Frontières, this time related to work in Athens. Interpretation is then tackled with Filiz Celik and Tom Cheesman from Swansea University in Wales addressing whether non-professional translation by volunteers from the same country can be a useful tool in counselling for refugees and torture survivors in a context where professional interpretation is unaffordable. Mechthild Wenk-Ansohn, Carina Heeke, Maria Böttche and Nadine Stammel from Center ÜBERLEBEN in Berlin present results of a multimodal treatment for newly arrived refugees that puts the focus on the initial six months' work; they found mixed results and reflect on them. Caecilie Böck Buhmann, Jessica Carlsson and Erik Lykke Mortensen from the Competence Center for Transcultural Psychiatry in Denmark analyse the cultural acceptability of a western-style, trauma-focused programme combining CBT and antidepressants showing that satisfaction is linked to rapport with the survivor and not to clinical results. This collection of 
papers adds new data and knowledge and shows some new avenues of work and research especially regarding early detection, counselling in early stages of arrival and support in the long term. It could not have been possible without the invaluable help of Joost den Otter, past Editor-in-Chief of the Journal and Associated Guest-Editor for this Special Section. Papers that are not directly related to the Special Section include a review entitled 'Debility, dependency and dread: On the conceptual and evidentiary dimensions of psychological torture' by Ergun Cakal and perspectives piece on the development and organisation behind survivor activism at Freedom from Torture in the UK by Shameem Sadiq-Tang which offers a useful and practical guide. Whilst this offers many positive stories, the rest of the content in this issue suggests that, in the case of the migrant victims of torture, they are almost always deprived of any form of control over their lives by an unjust and alienating system.

\section{References}

Allsopp, J., Sigona, N., \& Phillimore, J. (2014). Poverty among refugees and asylum seekers in the UK An evidence and policy review. IRiS Working Paper Series, 1-46.

Alpes, J., Blondel, C., Preiss, N., \& Monras, M. S. (2017). Post-deportation risks for failed asylum seekers. Forced Migration Review, 54, 76-78.

Amnesty International. (2017). Human Rights in the context of forced returns. (Vol. 1). https://doi. org/10.1007/978-3-319-39351-3_10

Asgary, R., Charpentier, B., \& Burnett, D. C. (2012). Socio-Medical Challenges of Asylum Seekers Prior and After Coming to the US. Fournal of Immigrant and Minority Health. https://doi. org/10.1007/s10903-012-9687-2

Baker, B. F. (2017). The Hidden Costs of Mass Deportation. Anthropology News, 58(5), e319e323. https://doi.org/10.1111/AN.632

Ben Farhat, J., Blanchet, K., Juul Bjertrup, P., Veizis, A., Perrin, C., Coulborn, R. M., ... Cohuet, S. (2018). Syrian refugees in Greece: Experience with violence, mental health status, and access to information during the journey and while in Greece. BMC Medicine, 16(1), 1-12. https://doi. org/10.1186/s12916-018-1028-4

Brooker, S., Albert, S., Young, P., Steel, Z., Flynn, M., \& Flynn, M. (2016). Challenges to Providing Mental Health Care in Immigration Detention About the Global Detention Project Challenges to Providing Mental Health Care in Immigration Detention, (19).

Crisp, J. (2009). Refugees, persons of concern, and people on the move: The broadening boundaries of UNHCR. Refuge, 26(1), 73-76.

Daniel, E. V., \& Knudsen, J. C. (1995). Mistrusting refugees. Berkeley: University of California Press.

EATIP, GTNM/RJ, CINTRAS, \& SERSOC. (2002). Paisajes del Dolor, Senderos de esperanza. Salud mental y derechos humanos en el Cono Sur.

European Council. (2013). L 180/60. Common procedures for granting and withdrawing international protection.

Fazel, M., \& Silove, D. (2006). Detention of refugees. British Medical fournal, 332(7536), 251-252. https://doi.org/10.1136/bmj.332.7536.251

Filges, T., Montgomery, E., \& Kastrup, M. (2018). The Impact of Detention on the Health of Asylum Seekers: A Systematic Review. Research on Social Work Practice, 28(4), 399-414. https:// doi.org/10.1177/1049731516630384

Freedom for Torture. (2012). Sri Lankan Tamils tortured on return from the UK.

Freedom for Torture. (2016). Proving Torture. Demanding the impossible. Home Office mistreatment of expert medical evidence. London.

Gadeberg, A. K., \& Norredam, M. (2016). Urgent need for validated trauma and mental health screening tools for refugee children and youth. European Child \& Adolescent Psychiatry, 25(8), 929-931. https://doi.org/10.1007/s00787-0160837-2

Good, A. (2004). Undoubtedly an expert? anthropologists in British asylum courts. Fournal of The Royal Anthropology Institute, 10, 113-133. https://doi.org/10.1111/j.14679655.2004.00182.x

Griffiths, M. (2012). Vile liars and truth distorters. Anthropology Today, 28(5).

Gyulai, G., Kagan, M., Herlihy, J., Turner, S., \& Lilli, H. (2013). Credibility assessment in asylum procedures. A Multidisciplinary Training Manual (Vol. 1). Hungarian Helsinki Committee.

Haas, B. M. (2017). Citizens-in-Waiting, Deporteesin-Waiting: Power, Temporality, and Suffering in the U.S. Asylum System. Ethos, 45(1), 75-97. https://doi.org/10.1111/etho.12150

Haoussou, K. (2017). Perspective-The long journey 
to rehabilitation for torture survivors i. Torture, 27(1), 66-74.

Hocking, D. C., Kennedy, G. A., \& Sundram, S. (2015). Mental disorders in asylum seekers: The role of the refugee determination process and employment. Fournal of Nervous and Mental Disease, 203(1), 28-32. https://doi.org/10.1097/ NMD.0000000000000230

Hollifield, M., Verbillis-Kolp, S., Farmer, B., Toolson, E. C., Woldehaimanot, T., Yamazaki, J., ... SooHoo, J. (2013). The Refugee Health Screener-15 (RHS-15): development and validation of an instrument for anxiety, depression, and PTSD in refugees. General Hospital Psychiatry, 35(2), 202-209. https://doi. org/10.1016/j.genhosppsych.2012.12.002

Home Office. (2015). Asylum Policy Instruction: Assessing Credibility and Refugee Status.

Hope Border Institute. (2018). Sealing the border. The criminalization of asylum seekers in the Trump era. El Paso.

HRW. (2012). UK: Halt Deportations of Tamils to Sri Lanka.

Human Rights First. (2017). Violations at the Border, (February). Retrieved from http:// www.humanrightsfirst.org/sites/default/files/hrfviolations-at-el-paso-border-rep.pdf

IRCT. (2016). Falling Through the Cracks: Asylum procedures and reception conditions for torture victims in the European Union. Copenhahue: IRCT.

Iversen, V. C., \& Morken, G. (2004). Differences in acute psychiatric admissions between asylum seekers and refugees. Nordic fournal of Psychiatry, 58(6), 465-470. https://doi. org/10.1080/08039480410011696

Jesuit Refugee Service - Europe. (2010). Becoming vulnerable in detention - Civil Society Report on the Detention of Vulnerable Asylum Seekers and Irregular Migrants in the European Union (DEVAS).

Johnson, H., \& Thompson, A. (2008). The development and maintenance of post-traumatic stress disorder (PTSD) in civilian adult survivors of war trauma and torture: a review. Clinical Psychology Review, 28, 36-47. https://doi. org/10.1016/j.cpr.2007.01.017

Johnston, V., Allotey, P., Mulholland, K., \& Markovic, M. (2009). Measuring the health impact of human rights violations related to Australian asylum policies and practices: A mixed methods study. BMC International Health and Human Rights, 9 (1).

Jubany, O. (2017). Screening asylum in a culture of disbelief: Truths, denials and skeptical borders. Screening Asylum in a Culture of Disbelief: Truths, Denials and Skeptical Borders. https://doi. org/10.1007/978-3-319-40748-7
Kalt, A., Hossain, M., Kiss, L., \& Zimmerman, C. (2013). Asylum seekers, violence and health: A systematic review of research in highincome host countries. American fournal of Public Health, 103(3). https://doi.org/10.2105/ AJPH.2012.301136

Kane, J. (2008). Judging Credibility. New York: American Bar Association.

Keller, A. S., Rosenfeld, B., Trinh-Shevrin, C., Meserve, C., Sachs, E., Leviss, J. A., ... Ford, D. (2003). Mental health of detained asylum seekers. Lancet, 362(9397), 1721-1723. https:// doi.org/10.1016/S0140-6736(03)14846-5

Khosravi, S. (2018). After deportation. Ethographic perspectives. Palgrave McMillan.

Loneragan, C., Steel, Z., Touze, D. le, Harris, E., Ceollo, M., Susljik, I., ... Brooks, R. (2006). Torture, Mental Health Status and the Outcomes of Refugee Applications among Recently Arrived Asylum Seekers in Australia. International fournal of Migration, Health and Social Care. https://doi. org/10.1108/17479894200600002

Lustig, S. L., Kureshi, S., Delucchi, K. L., Iacopino, V., \& Morse, S. C. (2008). Asylum grant rates following medical evaluations of maltreatment among political asylum applicants in the United States. Fournal of Immigrant and Minority Health / Center for Minority Public Health, 10, 7-15. https://doi.org/10.1007/s10903-007-9056-8

Lyytinen, E. (2017). Refugees' 'Journeys of Trust': Creating an Analytical Framework to Examine Refugees' Exilic Journeys with a Focus on Trust. fournal of Refugee Studies, few035. https://doi. org/10.1093/jrs/few035

Mackey, A., \& Barnes, J. (2013). Assessment of Credibility in Refugee and Subsidiary Protection claims under the EU Qualification Directive Fudicial criteria and standards Prepared by Allan Mackey and fohn Barnes for the International Association of Refugee.

Masinda, M. T. (2004). Quality of Memory: Impact on Refugee Hearing Decisions. Traumatology. https://doi.org/10.1177/153476560401000205

McColl, H., McKenzie, K., \& Bhui, K. (2008). Mental healthcare of asylum-seekers and refugees. Advances in Psychiatric Treatment, 14, 452-459. https://doi.org/10.1192/apt. bp. 107.005041

Mewes, R., Friele, B., \& Bloemen, E. (2018). Validation of the Protect Questionnaire: A Tool to Detect Mental Health Problems in Asylum Seekers by Non-Health Professionals. Torture, This issue.

Mind. (2010). Achieving justice for victims and witnesses with mental distress. A mental health toolkit for 
prosecutors and advocates. London: Mind-For better health.

Momartin, S., Silove, D., Manicavasagar, V., \& Steel, Z. (2003). Dimensions of trauma associated with posttraumatic stress disorder (PTSD) caseness, severity and functional impairment: a study of Bosnian refugees resettled in Australia. Social Science \& Medicine, 57(5), 775-781. https://doi. org/10.1016/S0277-9536(02)00452-5

Montgomery, E. (2011). Trauma, Exile and Mental Health in Young Refugees. Acta Psychiatrica Scandinavica, 124(September).

Mueller, J., Schmidt, M., Staeheli, A., \& Maier, T. (2011). Mental health of failed asylum seekers as compared with pending and temporarily accepted asylum seekers. European fournal of Public Health, 21(2), 184-189. https://doi. org/10.1093/eurpub/ckq016

Níraghallaigh, M. (2014). The causes of mistrust amongst asylum seekers and refugees: Insights from research with unaccompanied asylumseeking minors living in the republic of Ireland. Fournal of Refugee Studies, 27(1), 82-100. https:// doi.org/10.1093/jrs/fet006

Onyoin, C. A. (2017). A grim return : postdeportation risks in Uganda. Forced Migration Review, (February), 81-83.

Pearman, A., Psych, B., Olinga-shannon, S., \& Hons, B. B. A. (2017). Australian immigration detention and the silencing of practitioners, 90-93.

Pérez-Sales, P. (2017a). Psychological Torture: definition, evaluation and measurement. LondonNew York: Routledge.

Pérez-Sales, P. (2017b). Psychotherapy for torture survivors-Suggested pathways for research. Torture : Quarterly fournal on Rehabilitation of Torture Victims and Prevention of Torture, 27(1), 1-12.

Pérez-sales, P., Witcombe, N., \& Otero Oyague, D. (2017). Rehabilitation of torture survivors and prevention of torture: Priorities for research through a modified Delphi Study. Torture, 27(3), 3-48

Pettitt, J. (2013). The Poverty Barrier: The Right to Rehabilitation for Survivors of Torture in the UK, (July).

Porter, M. (2007). Global Evidence for a Biopsychosocial Understanding of Refugee Adaptation. Transcultural Psychiatry, 44, 418. https://doi.org/10.1177/1363461507081642

Porter, M., \& Haslam, N. (2005). Predisplacement and postdisplacement factors associated with mental health of refugees and internally displaced persons: A meta-analysis. Fournal of the American Medical Association, 294(5), 602-612. https://doi. org/10.1001/jama.294.5.602
PROTECT Project. (2016). PROTECT. Process of Recognition and Orientation of Torture Victims in European Countries to Facilitate Care and Treatment. Brussels.

Quinn, N. (2014). Participatory action research with asylum seekers and refugees experiencing stigma and discrimination: the experience from Scotland. Disability and Society, 29(1), 58-70. https://doi.org/10.1080/09687599.2013.769863

Ramos, C. (2011). Unsafe Return: Refoulement of Congolese Asylum Seekers.

Robinson, V., \& Segrott, J. (2002). Understanding the decision-making of asylum seekers. Home Office Research Study, (243), 84.

Robjant, K., Hassan, R., \& Katona, C. (2009). Mental health implications of detaining asylum seekers: systematic review. British fournal of Psychiatry, 194(4), 306-312. https://doi. org/10.1192/bjp.bp.108.053223

Roman, E., Baird, T., \& Radcliffe, T. (2016). Why Turkey is Not a "Safe Country." Statewatch Analysis, 2013(February), 1-26.

Rosenthal, E. (2018). The right of people with disabilities to asylum and protection from deportation on the grounds of Persecution or Torture Related to their disability.

Schock, K., Rosner, R., \& Knaevelsrud, C. (2015). Impact of asylum interviews on the mental health of traumatized asylum seekers. European fournal of Psychotraumatology, 6(March). https://doi. org/10.3402/ejpt.v6.26286

Silove, D. (2000). Policies of Deterrence and the Mental Health of Asylum Seekers. Fama, 284(5), 604. https://doi.org/10.1001/jama.284.5.604

Silove, D. (2013). The ADAPT model: a conceptual framework for mental health and psychosocial programming in post conflict settings. Intervention, 11(3), 237-248.

Sobhanian, F., Boyle, G. J., \& Bahr, M. (2006). Living in the Australian Community Psychological Status of Former Refugee Detainees From the Woomera Detention Centre Now Living in the Australian Community. Psychiatry, Psychology and Law, 13(2), 37-41.

Special Rapporteur Against Torture. (2018). Migration-related torture and ill-treatment (A/ HRC/37/50). United Nations. https://doi.org/ $\mathrm{CAT} / \mathrm{C} / \mathrm{MAR} / \mathrm{CO} / 4$

Stedman, S. J., \& Tanner, F. (2003). Refugee manipulation. War, politics and the abuse of human suffering. Washington: Brookings Institution Press.

Steel, Z., Chey, T., Silove, D., Marnane, C., Bryant, R. A., van Ommeren, M., \& Steel Z, Chey T, Silove D, Marnane C, Bryant RA, van O. M. (2009). Association of torture and other 
potentially traumatic events with mental health outcomes among populations exposed to mass conflict and displacement: a systematic review and meta-analysis. FAMA : The fournal of the American Medical Association, 302(5), 537-549. https://doi.org/10.1001/jama.2009.1132

Steel, Z., \& Silove, D. M. (2001). The mental health implications of detaining asylum seekers. Medical Fournal of Australia, 175, 596-599.

Stefanovska, V. (2016). Diplomatic Assurances and the State' s Responsibility When Considering Extraditing a Person Whose Human Rights May Be Violated. VARSTVOSLOVFE, fournal of Criminal Fustice and Security, (2), 167-182.

Storm, T., \& Engberg, M. (2013). The impact of immigration detention on the mental health of torture survivors is poorly documented - A systematic review. Danish Medical fournal, 60(11), 1-7.

Tay, A. K., \& Silove, D. (2017). The ADAPT model: bridging the gap between psychosocial and individual responses to mass violence and refugee trauma. Epidemiology and Psychiatric Sciences, 26(02), 142-145. https://doi.org/10.1017/ S2045796016000925

Tirado, M. C. and I. G.-S. (2008). Quality in and Equality of Access to Healthcare Services. Country Report for Romania. Brussells.

Ulusoy, O., \& Battjes, H. (2017). Situation of Readmitted Migrants and Refugees from Greece to Turkey under the EU-Turkey Statement, (15), $1-42$.

UNHCR-International Detention Coalition - OAK. (2016). Vulnerability Screening Tool. Identifying and addressing vulnerability: a tool for asylum and migration systems.

UNHCR. (2017). UNHCR-Global Trends. Forced displacement in 2016. Geneva. Switzerland.

United Nations High Commisioner for Refugees. (2012). Detention guidelines. UNHCR.

Viñar, M. (2007). Civilization and torture : beyond the medical and psychiatric approach. International Review of the Red Cross, 89(867), 619-633.

Voutira, E., \& Harrell-Bond, B. (1995). In search of the locus of trust: the social world of the refugee camp. In E. V. Daniel \& J. C. Knudsen (Eds.), Mistrusting refugees (pp. 207-225). University of California Press. 